\title{
HLA antigens in systemic lupus erythematosus
}

\author{
C. DOSTÁL, D. IVÁNYI, H. MACUROVÁ, I. HÁNA, AND J. STREJČEK \\ From the Research Institute of Rheumatic Diseases; Institute of Dental Research; Institute of Clinical and \\ Experimental Medicine; Postgraduate Medicinal and Pharmaceutical Institute of Rheumatic Diseases; and \\ Department of Medicine, Charles University, Prague, Czechoslovakia
}

SUMMARY Forty-five patients suffering from systemic lupus erythematosus were studied in respect of their serologically defined HLA antigens. HLA-B8 antigen was found in $37.8 \%$ of patients as compared to $22 \%$ of controls. Individuals carrying the HLA-B8 antigen have a $2 \cdot 15$ times greater risk of developing systemic lupus erythematosus than those not carrying this antigen.

Associations between the antigens of the major histocompatibility system in man (HLA) and some diseases have been studied by several workers. In diseases where the involvement of autoantibodies in the pathogenesis was assumed or proved, an increased frequency of HLA-B8 was found, e.g. in chronic aggressive autoimmune hepatitis, myasthenia gravis, coeliac disease, thyrotoxicosis, insulindependent diabetes, idiopathic Addison's disease, and Sjøgren's syndrome.

The distribution of HLA antigens in systemic lupus erythematosus (SLE) has been studied by several authors (Table 1). However, the results were not conclusive: generally only weak associations between SLE and HLA antigens were found by some and questionable results or lack of any association were found by others (Table 1).

The proved association between HLA-B8 and some autoimmune diseases together with the possible association of this antigen with SLE (Grumet et al., 1971; Goldberg et al., 1973; Stenszky et al., 1973) attracted our attention. We therefore investigated the frequency of individual HLA antigens, with special reference to HLA-B8, in SLE patients in the Research Institute of Rheumatic Diseases and Clinical Ward of the Medical Faculty, Charles University, Prague.

\section{Material and methods}

A total of 45 Czech patients with SLE (38 females, 7 males) were investigated. Their ages ranged from 15 to 75 years, mean 44 years. The diagnosis of SLE was established by the presence of at least four

Accepted for publication May 24, 1976

Correspondence to Dr. C. Dostál, Research Institute of Rheumatic Diseases, Na slupi č. 4, 12000 Praha 2, Czechoslovakia of the preliminary criteria for the classification of SLE proposed by the American Rheumatism Association and by the presence of antinuclear serum antibodies as determined by immunofluorescence (Coons and Kaplan, 1950). The controls consisted of 350 unrelated Caucasians whose HLA antigens had been typed in the same laboratory (Ivašková et al., 1974).

HLA typing was performed by the lymphocytotoxic microtechnique using peripheral lymphocytes. 21 antigens were typed (Table 2). Three to six monoor oligospecific antisera were used for the definition of each specificity. Differences in prevalence of HLA antigens between patients and controls were determined by the $\chi^{2}$ test. The corrected $P$ value was calculated by multiplying $\mathbf{P}$ by the number of antigens tested. The relative risk for a given antigen, indicating how many times more frequent it is in individuals carrying this antigen than in those lacking it, was calculated according to Svejgaard et al. (1974).

\section{Results}

The distribution of HLA antigens in patients with SLE and in controls is given in Table 2. HLA-B8 was found in $37.8 \%$ of the patients as compared with $22 \%$ of the controls $(P<0.025)$. Despite this difference, the corrected $\mathbf{P}$ value is not significant. The distribution of other HLA antigens compares well with that in the control group. The relative risk of SLE for HLA-B8 is 2.15 (the $95 \%$ confidence interval is 1.14-4.06).

The percentage of patients meeting the individual criteria for classification of SLE is given in Table 3. A multifactorial analysis of these and many other clinical and laboratory parameters and their possible relation to HLA-B8 antigen is in progress. 
84 Dostál, Iványi, Macurová, Hána, Strejček

Table 1 HLA antigen in SLE: survey of literature

\begin{tabular}{|c|c|c|c|c|c|c|c|c|c|}
\hline \multirow[t]{2}{*}{ Author } & \multirow{2}{*}{$\begin{array}{l}\text { No. of } \\
\text { patients }\end{array}$} & \multirow{2}{*}{$\begin{array}{l}\text { No. of } \\
\text { controls }\end{array}$} & \multirow[t]{2}{*}{ Race } & \multirow[t]{2}{*}{ Antigens } & \multicolumn{2}{|c|}{$\%$ positive } & \multirow{2}{*}{$\begin{array}{l}\text { No. of } \\
\text { antigens } \\
\text { tested }\end{array}$} & \multirow[t]{2}{*}{$P$ corrected } & \multirow{2}{*}{$\begin{array}{l}\text { Relative } \\
\text { risk }\end{array}$} \\
\hline & & & & & Patients & Controls & & & \\
\hline $\begin{array}{l}\text { Grumet et al. } \\
\text { (1971) }\end{array}$ & $25 \dagger$ & 82 & Caucasian & $\begin{array}{l}\text { HLA-B8 } \\
\text { HLA-Bw15 }\end{array}$ & $\begin{array}{l}36 \\
36\end{array}$ & $\begin{array}{l}16 \\
10\end{array}$ & 21 & \multirow[t]{2}{*}{$\begin{array}{l}>0.05 \\
>0.05\end{array}$} & \multirow[t]{2}{*}{$\begin{array}{l}2 \cdot 95 \\
5 \cdot 20\end{array}$} \\
\hline $\begin{array}{l}\text { Bitter } \text { et al. } \\
\quad \text { (1972) }\end{array}$ & 28 & 280 & Black & $\begin{array}{l}\text { HLA-B7 } \\
\text { HLA-Bw35 }\end{array}$ & $\begin{array}{l}50 \\
50\end{array}$ & $\begin{array}{l}<10 \\
<10\end{array}$ & $?$ & & \\
\hline $\begin{array}{l}\text { Stastny } \\
\text { (1972) }\end{array}$ & 40 & 40 & Black & $\begin{array}{l}\text { HLA-Aw19 } \\
\text { HLA-B5 }\end{array}$ & $52 \cdot 5 * *$ & $<7 \cdot 5$ & 22 & $<0.01$ & $13 \cdot 6$ \\
\hline \multirow{2}{*}{$\begin{array}{l}\text { Goldberg et al. } \\
\text { (1973)* }\end{array}$} & 120 & 120 & \multirow{2}{*}{$\begin{array}{l}\text { Caucasian } \\
\text { Mexican } \\
\text { Black }\end{array}$} & HLA-A1 & 22 & 9 & \multirow[t]{2}{*}{23} & \multirow{2}{*}{$\begin{array}{l}>0.05 \\
>0.05\end{array}$} & \multirow{2}{*}{$\begin{array}{l}2 \cdot 85 \\
2 \cdot 69\end{array}$} \\
\hline & matched & ace & & HLA-B8 & & & & & \\
\hline $\begin{array}{l}\text { Suciu-Foca et al. } \\
\quad(1974)\end{array}$ & 53 & 80 & ? & $\begin{array}{l}\text { HLA-A11 } \\
\text { 4C (W5, W18) }\end{array}$ & $\begin{array}{l}21 \\
47\end{array}$ & $\begin{array}{l}11 \\
24\end{array}$ & 26 & $\begin{array}{l}>0.05 \\
>0.05\end{array}$ & $\begin{array}{l}2 \cdot 15 \\
2 \cdot 81\end{array}$ \\
\hline \multirow[t]{4}{*}{$\begin{array}{l}\text { Nies et al. } \\
\quad \text { (1974) }\end{array}$} & 42 & 886 & Caucasian & $\begin{array}{l}\text { HLA-A10 } \\
\text { HLA-B5 }\end{array}$ & $\begin{array}{l}24 \\
24\end{array}$ & $\begin{array}{l}27 \\
11 \\
11\end{array}$ & \multirow[t]{4}{*}{25} & $\begin{array}{l}>0.05 \\
>0.05\end{array}$ & $\begin{array}{l}2 \cdot 55 \\
2 \cdot 55\end{array}$ \\
\hline & 40 & 283 & Mexican & HLA-B5 & 28 & 17 & & $>0.05$ & 1.90 \\
\hline & & 120 & & HLA-Bw40 & 28 & 12 & & $>0.05$ & $2 \cdot 85$ \\
\hline & $\begin{array}{l}40 \\
90\end{array}$ & $450 \ddagger$ & Black & HLA-B5 & 23 & 5 & & $>0.05$ & $5 \cdot 66$ \\
\hline \multirow{3}{*}{$\begin{array}{l}\text { Stenzky et al. } \\
\text { (1973) }\end{array}$} & 90 & & Caucasian & $\begin{array}{l}\text { HLA-A2 } \\
\text { HLA-B5 }\end{array}$ & $\begin{array}{l}64 \cdot 4 \\
33 \cdot 3\end{array}$ & $\begin{array}{l}48 \cdot 1 \\
19 \cdot 4\end{array}$ & \multirow[t]{3}{*}{20} & $\begin{array}{l}>0.05 \\
>0.05\end{array}$ & $\begin{array}{l}1.95 \\
2.07\end{array}$ \\
\hline & & & & HLA-B8 & $32 \cdot 2$ & $19 \cdot 1$ & & $>0.05$ & $2 \cdot 01$ \\
\hline & & & & HLA-Bw40 & $3 \cdot \overline{3}$ & $16 \cdot 1$ & & $<0.05$ & $0 \cdot 18$ \\
\hline \multirow{2}{*}{\multicolumn{3}{|c|}{$\begin{array}{l}\text { Kissmeyer-Nielsen } 65 \\
\text { et al. }(1975) \\
\text { Watters et al. } \\
\quad(1971)\end{array}$}} & Caucasian & \multirow{2}{*}{\multicolumn{5}{|c|}{$\begin{array}{l}\text { No significant (after correction) } \\
\text { deviation found } \\
\text { In } 15 \text { patients a questionable frequency increase of Bw15-related antigen } \\
\text { Patients were not matched for race (mixed) with controls }\end{array}$}} & \\
\hline & & & & & & & & & \\
\hline
\end{tabular}

P corrected and relative risks were calculated from data in each paper

* Results from Arnett et al. (1972) are included in this paper.

$\dagger$ Out of 40 SLE patients tested only 25 were matched for race with controls.

$\ddagger$ Personal communication.

$\S$ Defined by serum TH-Li.

** Twofold increase in comparison with controls; frequency in controls not given.

Table $2 H L A$ antigen frequency in 45 SLE patients compared with 350 controls

\begin{tabular}{|c|c|c|c|c|}
\hline \multirow[t]{2}{*}{$H L A$} & \multicolumn{2}{|c|}{ Controls } & \multicolumn{2}{|c|}{ Patients } \\
\hline & No. & $\%$ & No. & $\%$ \\
\hline \multicolumn{5}{|c|}{ First locus } \\
\hline A1 & 112 & $32 \cdot 0$ & 17 & $37 \cdot 8$ \\
\hline A2 & 168 & $48 \cdot 0$ & 16 & $35 \cdot 5$ \\
\hline A3 & 106 & 30.0 & 15 & $33 \cdot 3$ \\
\hline A9 & 51 & $14 \cdot 5$ & 8 & $17 \cdot 8$ \\
\hline A10 & 67 & $19 \cdot 1$ & 7 & $15 \cdot 5$ \\
\hline A11 & 31 & 8.9 & 8 & $17 \cdot 8$ \\
\hline A28 & 35 & $10 \cdot 0$ & 0 & 0.0 \\
\hline \multicolumn{5}{|c|}{ Second locus } \\
\hline B5 & 44 & $12 \cdot 6$ & 5 & $11 \cdot 1$ \\
\hline B7 & 77 & $22 \cdot 0$ & 14 & $31 \cdot 1$ \\
\hline B8 & 77 & $22 \cdot 0$ & 14 & $37 \cdot 8^{*}$ \\
\hline B12 & 67 & $19 \cdot 1$ & 7 & $15 \cdot 5$ \\
\hline B13 & 25 & $7 \cdot 1$ & 5 & $11 \cdot 1$ \\
\hline B14 & 9 & $2 \cdot 5$ & 1 & $2 \cdot 2$ \\
\hline B18 & 50 & $14 \cdot 4$ & 3 & 6.7 \\
\hline B27 & 28 & 8.0 & 5 & $11 \cdot 1$ \\
\hline Bw15 & 45 & $12 \cdot 8$ & 2 & $4 \cdot 4$ \\
\hline Bw17 & 26 & $7 \cdot 4$ & 3 & $4 \cdot 4$ \\
\hline Bw21 & 23 & $6 \cdot 5$ & 0 & 0.0 \\
\hline Bw22 & 15 & $4 \cdot 3$ & 3 & 6.7 \\
\hline Bw35 & 68 & $19 \cdot 4$ & 9 & $20 \cdot 0$ \\
\hline Bw40 & 34 & $9 \cdot 7$ & 2 & $4 \cdot 4$ \\
\hline
\end{tabular}

${ }^{*} \mathrm{P}<0.025 . \mathrm{P}$ corrected $>0.05$.

The relative risk of SLE for HLA-B8 is $2.15(95 \%$ confident limits 1.14-4.06).
Table 3 Percentage of 45 patients meeting the preliminary criteria for the classification of $S L E$

\begin{tabular}{|c|c|}
\hline Criterion & $\%$ \\
\hline Facial erythema & $71 \cdot 11$ \\
\hline Discoid lupus & $13 \cdot 33$ \\
\hline Raynaud's phenomenon & 35.55 \\
\hline Alopecia & $42 \cdot 85$ \\
\hline Photosensitivity & 26.66 \\
\hline Oral or nasal ulcers & 0 \\
\hline Arthritis without deformity & $93 \cdot 33$ \\
\hline $\begin{array}{l}\text { LE-cells } \\
\end{array}$ & $84 \cdot 44$ \\
\hline Chronic false-positive STS & 0 \\
\hline Profuse proteinuria & $26 \cdot 65$ \\
\hline Cellular casts & $55 \cdot 33$ \\
\hline Pleuritis & $40 \cdot 00$ \\
\hline Pericarditis & $13 \cdot 33$ \\
\hline Psychosis & 4.44 \\
\hline Convulsions & $17 \cdot 77$ \\
\hline Haemolytic anaemia & 4.44 \\
\hline Leucopenia & $60 \cdot 00$ \\
\hline Thrombocytopenia & $20 \cdot 00$ \\
\hline
\end{tabular}

The increased frequency of HLA-B8 antigen four in our group of patients agrees with data previousf published (Grumet et al., 1971; Goldberg et at. 1973; Stenszky et al., 1973) concerning an associ tion between this antigen and SLE. This association was not found to be significant in any of the abogeg 
reports nor in our study after $\mathbf{P}$ values had been corrected for the number of antigens tested. However, the combined relative risk for HLA-B8 calculated from all these data (467 SLE patients) is highly significant (Ivanyi et al., 1976).

In addition to HLA-B8, three cross-reacting antigens, HLA-Bw35, HLA-B5, and HLA-Bw15, have most frequently been mentioned in the literature in association with SLE (Table 1). It is interesting that while an increased frequency of HLA-B8 antigen has been described in several autoimmune diseases, an association of one of these, namely Graves's disease, with HLA-Bw35 was found recently in Japanese patients (Grumet et al., 1975). Accordingly, the occurrence of different HLA antigens in association with the same disease in different ethnic groups may be expected for other HLA-B8associated diseases as well. The association of SLE with HLA-Bw35 (Bitter et al., 1972), HLA-B5 (Nies et al., 1974; Stastny, 1972), and HLA-Bw15 antigens (Grumet et al., 1971), seen mainly in nonCaucasian patients (see Table 1), agrees with this assumption.

Further data are needed to permit calculation of the combined relative risk for the above-mentioned group of antigens in SLE. Nevertheless, the available data may indicate that Ir genes which control the ability to mount an autoimmune reaction occur in linkage disequilibrium with HLA-B8 in Caucasians and with antigens of the cross-reacting group HLA-Bw35, HLA-B5, and HLA-Bw15 in nonCaucasians. Interestingly, insulin-dependent juvenile diabetes mellitus is associated with both HLA-B8 and HLA-Bw15 antigens (Nerup et al., 1974). The associations between HLA antigens and some diseases are most frequently interpreted as the result of HLA-linked gene action controlling the immune response to various antigens and the susceptibility to certain viruses. This interpretation is based on the analogy of the HLA system with the mouse $\mathbf{H}-2$ system, where these genes have already been precisely located. However, the mouse $\mathrm{H}-2$ system is also associated with a genetic factor that regulates the level of complement and influences the metabolism of androgen hormones and cAMP (for review see Iványi, 1975). The possible analogies in man offer alternative interpretations of HLA and disease associations.

We are indebted to Dr. L. Mrklas for statistical evaluation of the data.

\section{References}

Arnett, F. C., Bias, W. B., and Shulman, L. E. (1972). HL-A antigens in systemic lupus erythematosus. Arthritis and Rheumatism, 15, 428.

Bitter, T., Mottironi, W. D., and Terasaki, P. I. (1972). HL-A antigens associated with lupus erythematosus. New England Journal of Medicine, 286, 435.

Coons, A. H., and Kaplan, M. H. (1950). Localization of antigen in tissue cells. II. Improvements in a method for the detection of antigen by means of fluorescent antibody. Journal of Experimental Medicine, 91, 1-4.

Goldberg, M. A., Arnett, F. C., Bias, M. B., and Shulman, L. E. (1973). Histocompatibility (HL-A) antigens in systemic lupus erythematosus. Arthritis and Rheumatism, 16, 546-547.

Grumet, F. C., Coukell, A., Bodmer, W. F., and McDevitt, H. C. (1971). Histocompatibility (HL-A) antigens associated with systemic lupus erythematosus. New England Journal of Medicine, 285, 193-196.

Grumet, F. C., Payne, R. O., Konishi, J., Mort, T., and Kriss, J. P. (1975). HLA antigens in Japanese patients in Graves's disease. Tissue Antigens, 6, 347-352.

Iványi, P. (1975). Quantitative variations in physiological traits influenced by the H-2 system. Folia Biologica, 21, 444-448.

Iványi, D., Dostál, C., and Mrklas, L. (1976). HLA-B8 in systemic lupus erythematosus. Tissue Antigens (in press).

Ivaškova, E., Bavorová, H., Macurová, H., Pellar, L., and Iványi, P. (1974). Identification of leukocyte antigen and its importance in clinical works (in Czech). Casopis lékařu ceskych, 113, 1505-1507.

Kissmeyer-Nielsen, F., Kjerbye, K. E., Andersen, E., and Halberg, P. (1975). HL-A antigens in systemic lupus erythematosus. Transplantation Review, 22, 164-167.

Nerup, J., Platz, P., Ortved Andersen, O., Christy, M., Lyngsøe, J., Poulsen, J. E., Ryder, L. P., Thomsen, M., Staub-Nielsen, J., and Svejgaard, A. (1974). HL-A antigens and diabetes mellitus. Lancet, 2, 864-866.

Nies, K. M., Brown, J. C., Dubois, E. L., Quismorio, F. P., Friou, G. J., and Terasaki, P. I. (1974). Histocompatibility (HL-A) antigens and lymphocytotoxic antibodies in systemic lupus erythematosus (SLE). Arthritis and Rheumatism, 17, 397-402.

Stastny, P. (1972). The distribution of HL-A antigens in Black patients with systemic lupus erythematosus (SLE). Arthritis and Rheumatism, 15, 455-456.

Stenszky, V., Szegedi, Gy., Aszódi, L., and Petrányi, Gy. (1973). HL-A and systemic lupus erythematosus. Haematologia, 7, 211-217.

Suciu-Foca, N., Buda, J., Almojera, P., and Reemtsma, K. (1974). HL-A antigens and M.L.C. responsiveness in systemic lupus erythematosus. Lancet, 2, 726-727.

Svejgaard, A., Jersild, C., Staub-Nielsen, L., and Bodmer, W. F. (1974). HL-A antigens and disease. Statistical and genetical considerations. Tissue Antigens, 4, 95-105.

Watters, H., Konrad, P., and Walford, R. L. (1971). The distribution of HL-A histocompatibility factors and genes in patients with systemic lupus erythematosus. Tissue Antigens, 1, 68-73. 